\title{
Endoscopic extra-cavitary drainage of pancreatic necrosis with fully covered self-expanding metal stents (fcSEMS) and staged lavage with a high-flow water jet system
}

Authors

Institutions
Ioana B. Smith ${ }^{1,2}$, Juan P. Gutierrez ${ }^{1}$, Jayapal Ramesh' ${ }^{1}$, C. Mel Wilcox ${ }^{1}$, Klaus E. Mönkemüller ${ }^{1}$

${ }^{1}$ Department of Gastroenterology, University of Alabama at Birmingham, Birmingham, AL, USA

${ }^{2}$ Division of Internal Medicine, University of Alabama at Birmingham, Birmingham, AL, USA submitted 22. June 2014 accepted after revision 7. July 2014

\section{Bibliography}

Dol http://dx.doi.org/

10.1055/s-0034-1391481

Published online: 10.4.2015

Endoscopy International Open 2015; 03: E154-E160

(c) Georg Thieme Verlag KG Stuttgart · New York

E-ISSN 2196-9736

\section{Corresponding author} Klaus E. Mönkemüller, MD, PhD

Department of

Gastroenterology

University of Alabama at

Birmingham

BDB 389

1808 7th Ave. 5

Birmingham, AL 35294

USA

Fax: +1-205-934-1578

klaus1@uab.edu

moenkemueller@yahoo.com
Aim: To present a novel, less-invasive method of endoscopic drainage (ED) for walled-off pancreatic necrosis (WON).We describe the feasibility, success rate, and complications of combined ED extra-cavitary lavage and debridement of WON using a biliary catheter and high-flow water jet system (water pump).

Patients and methods: Endoscopic ultrasound (EUS)-guided drainage was performed with insertion of two 7-Fr, 4-cm double pigtail stents. Subsequently a fully covered self-expanding metal stent (fcSEMS) was placed. The key aspect of the debridement was the insertion of a 5-Fr biliary catheter through or along the fcSEMS into the cavity, with ensuing saline lavage using a highflow water jet system. The patients were then brought back for repeated, planned endoscopic lavages of the WON. No endoscopic intra-cavitary exploration was performed.

\section{Introduction}

Walled-off pancreatic necrosis (WON) is a liquefied necrosis greater than $30 \%$ of the gland size, and is a later complication of acute necrotizing pancreatitis usually occurring more than 4 weeks after the initial insult [1 -3]. Indications for drainage of WON include pain, infection, enlargement, gastric outlet or biliary obstruction, and leakage [4-10]. In the case of symptomatic or infected WON, direct endoscopic necrosectomy (DEN) can be utilized to remove the solid necrotic material but may require multiple sessions [3]. Alternatively, endoscopic drainage (ED) of pancreatic necrosis can be performed transmurally with drains and stents and may necessitate percutaneous drains as an adjunct [4]. Transmural ED with fully covered self-expanding metal stents (fcSEMS) has been proven useful for treating patients with complex pancreatic fluid collections (PFC) including WON. However, most studies evaluating fcSEMS have included the entire spectrum of PFC
Results: A total of 17 patients ( 15 men, 2 women; mean age 52.6, range 24-69; mean American Society of Anesthesiologists [ASA] score of 3 ) underwent ED of WON with this new method. The mean initial WON diameter was $9.5 \mathrm{~cm}$, range 8 to $26 \mathrm{~cm}$. The total number of ED was 84 , range 2 to 13 . The mean stenting period was 42.5 days. The mean follow-up was 51 days, range 3 to 370 . A resolution of the WON was achieved in 14 patients $(82.3 \%)$. There were no major complications associated with this method.

Conclusion: ED of complex WON with fcSEMS followed by repeated endoscopic extra-cavitary lavage and debridement using a biliary catheter and high-flow water jet system is a minimally invasive, feasible method with high technical and clinical success and minimal complications.

( $\bullet$ Table 1). In addition, most data on ED for WON propose endoscopic intra-cavitary debridement (i.e., direct passage of the endoscope into the cavity with necrosectomy), which is associated with a high rate of complications [11]. The aim of this study was to present a novel, less-invasive method of ED for WON using the concept of extra-cavitary saline lavage and debridement with a biliary catheter and high-flow water jet system. The main objectives were to analyze the feasibility, success rate, and complications of this new method.

\section{Patients and methods}

$\nabla$

This was a retrospective, observational, cohort study from October 2012 to October 2013 including 17 patients who underwent ED for WON at our tertiary care hospital. The inclusion criteria were symptomatic patients with WON older than age 18. Exclusion criteria included younger 
Table 1 Studies utilizing fully covered self-expanding metal stents (fCSEMS) for drainage of walled-off pancreatic necrosis (WON).

\begin{tabular}{|c|c|c|c|c|c|c|c|c|c|c|}
\hline Study & $\begin{array}{l}\text { No. of } \\
\text { pa- } \\
\text { tients }\end{array}$ & $\begin{array}{l}\text { No. of pro- } \\
\text { cedures } \\
\text { (by pa- } \\
\text { tient) }\end{array}$ & Etiology & $\begin{array}{l}\text { Largest } \\
\text { diameter } \\
(\mathrm{cm})\end{array}$ & Location & $\begin{array}{l}\text { Complica- } \\
\text { tions }\end{array}$ & $\begin{array}{l}\text { Technical } \\
\text { success (\%) }\end{array}$ & $\begin{array}{l}\text { Clinical } \\
\text { success (\%) }\end{array}$ & $\begin{array}{l}\text { With } \\
\text { stent } \\
\text { (wk) }\end{array}$ & $\begin{array}{l}\text { Follow- } \\
\text { up (wk) }\end{array}$ \\
\hline \multirow{4}{*}{$\begin{array}{l}\text { Yamamo- } \\
\text { to et al. } \\
{[3]}\end{array}$} & \multirow[t]{4}{*}{4} & 9 & * & 32 & * & \multirow[t]{4}{*}{ None } & \multirow[t]{4}{*}{100} & \multirow{4}{*}{$\begin{array}{l}50 \text { ( } 1 \text { required } \\
\text { surgical ne- } \\
\text { crosectomy } \\
\text { and } 1 \text { died) }\end{array}$} & 5.7 & ${ }^{*}$ \\
\hline & & - & * & 8 & $*$ & & & & - & * \\
\hline & & 3 & * & 30 & * & & & & - & * \\
\hline & & 4 & $*$ & 10 & $*$ & & & & 3.6 & $*$ \\
\hline \multirow{4}{*}{$\begin{array}{l}\text { Belle et } \\
\text { al. [5] }\end{array}$} & \multirow[t]{4}{*}{4} & 3 & \multirow{4}{*}{$\begin{array}{l}3 \text { biliary-induced } \\
\text { and } 1 \mathrm{ETOH}- \\
\text { induced }\end{array}$} & $*$ & * & None & \multirow[t]{4}{*}{100} & \multirow[t]{4}{*}{100} & 4 & 147 \\
\hline & & 3 & & * & * & $\begin{array}{l}\text { Transitory out- } \\
\text { let obstruction }\end{array}$ & & & 5 & 9 \\
\hline & & 2 & & * & $*$ & None & & & 9 & 5 \\
\hline & & 3 & & * & $*$ & None & & & 147 & 4 \\
\hline \multirow[t]{5}{*}{$\begin{array}{l}\text { Berzosa } \\
\text { et al. [1] }\end{array}$} & \multirow[t]{5}{*}{2} & 1 & $\begin{array}{l}\text { Gallstone } \\
\text { pancreatitis }\end{array}$ & 6 & Body & \multirow[t]{5}{*}{ None } & \multirow[t]{5}{*}{100} & \multirow[t]{5}{*}{100} & 11 & 22 \\
\hline & & - & - & 8 & Tail & & & & - & - \\
\hline & & - & - & - & - & & & & - & - \\
\hline & & 1 & $\begin{array}{l}\text { Pancreatic } \\
\text { abscess }\end{array}$ & 6 & Neck & & & & 8 & 7 \\
\hline & & - & - & 4 & Body & & & & - & - \\
\hline $\begin{array}{l}\text { Tarantino } \\
\text { et al. [7] }\end{array}$ & 1 & 1 & $\begin{array}{l}\text { Necrotizing acute } \\
\text { pancreatitis }\end{array}$ & 20 & Head, body & None & 100 & 100 & 12 & * \\
\hline $\begin{array}{l}\text { Fabbri et } \\
\text { al. [15] }\end{array}$ & 10 & * & $\begin{array}{l}\text { Acute biliary } \\
\text { pancreatitis }\end{array}$ & 10 & * & * & * & * & * & * \\
\hline- & - & * & $\begin{array}{l}\text { Alcoholic acute } \\
\text { pancreatitis }\end{array}$ & 15 & * & None & 100 & 100 & * & * \\
\hline- & - & - & $\begin{array}{l}\text { Surgical compli- } \\
\text { cation after } \\
\text { cholecystectomy }\end{array}$ & 6 & * & * & * & * & * & * \\
\hline- & - & * & $\begin{array}{l}\text { Acute biliary } \\
\text { pancreatitis }\end{array}$ & 20 & * & None & 100 & 100 & * & * \\
\hline- & - & * & $\begin{array}{l}\text { Acute biliary } \\
\text { pancreatitis }\end{array}$ & 15 & * & None & 100 & 100 & * & * \\
\hline - & - & * & $\begin{array}{l}\text { Post-ERCP } \\
\text { pancreatitis }\end{array}$ & 8 & * & None & 100 & 100 & * & * \\
\hline - & - & * & $\begin{array}{l}\text { Acute biliary } \\
\text { pancreatitis }\end{array}$ & 16 & * & None & 100 & 100 & * & * \\
\hline- & - & * & $\begin{array}{l}\text { Acute biliary } \\
\text { pancreatitis }\end{array}$ & 18 & * & None & 100 & 100 & * & * \\
\hline - & - & * & $\begin{array}{l}\text { Acute biliary } \\
\text { pancreatitis }\end{array}$ & 20 & * & None & 100 & 100 & $*$ & * \\
\hline - & - & * & $\begin{array}{l}\text { Acute biliary } \\
\text { pancreatitis }\end{array}$ & 20 & * & $\begin{array}{l}\text { Migration and } \\
\text { sepsis } \\
\text { (surgery) }\end{array}$ & * & * & * & * \\
\hline $\begin{array}{l}\text { Hritz et } \\
\text { al. [14] }\end{array}$ & 4 & * & $\begin{array}{l}\text { Gallstone } \\
\text { pancreatitis }\end{array}$ & 14 & $\begin{array}{l}\text { Stomach and } \\
\text { body of the } \\
\text { pancreas }\end{array}$ & None & 100 & 75 & 1 & 6 \\
\hline- & - & * & * & 11 & $\begin{array}{l}\text { Posterior } \\
\text { wall of the } \\
\text { stomach and } \\
\text { the pancreas }\end{array}$ & None & & & 1 & 6 \\
\hline- & - & * & Idiopathic & 10 & Retrogastric & None & & & 1 & 6 \\
\hline- & - & * & $*$ & 8.5 & $*$ & None & & & 1 & 6 \\
\hline
\end{tabular}

Abbreviation: $\mathrm{ETOH}$, ethanol.

* Not mentioned.

than age 18, pregnancy, and coagulopathy (international normalized ratio [INR] $>1.4$, platelets $<40000$ ). All patients provided written and informed consent to undergo the procedure. The study was conducted following the guidelines of Helsinki and was approved by the ethics committee of our institution. The procedures were performed with patients under monitored anesthesia care or general anesthesia. A prophylactic antibiotic (ciprofloxacin $400 \mathrm{mg}$, IV) was administered before beginning the procedure in all patients. A 3.7-mm channel, linear echoendoscope (GFUCT160, Olympus America, Melville, NY, USA) was used to access the WON via either the stomach or duodenal wall under fluoroscopic guidance. The cavity was punctured with a 19-gauge EUS needle (Cook, Winston-Salem, NC, USA) and a fluid sample was aspirated and sent for microscopic analysis. Then a 0.035-inch guidewire (Metro, Cook) was inserted through the needle into the cavity, and coiling into the cavity was confirmed 

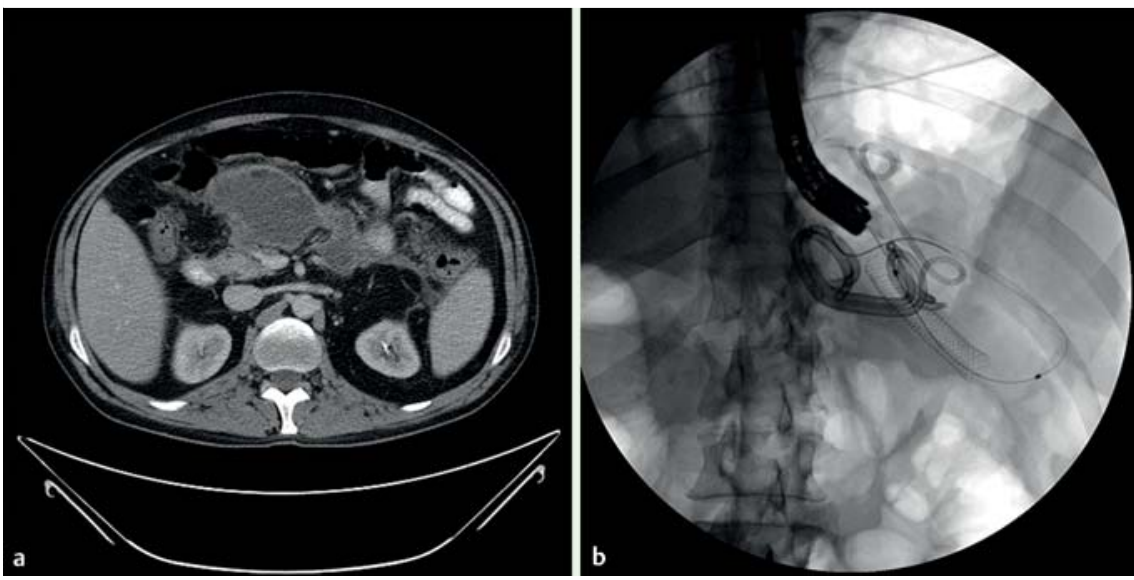

Fig. 1 Walled-off pancreatic necrosis (WON).

(a) The computed tomography (CT) shows a WON.

(b) Once the cystenterostomy tract was created with endoscopic ultrasound, a fully covered selfexpanding metal stent (fCSEMS) was inserted into the collection.
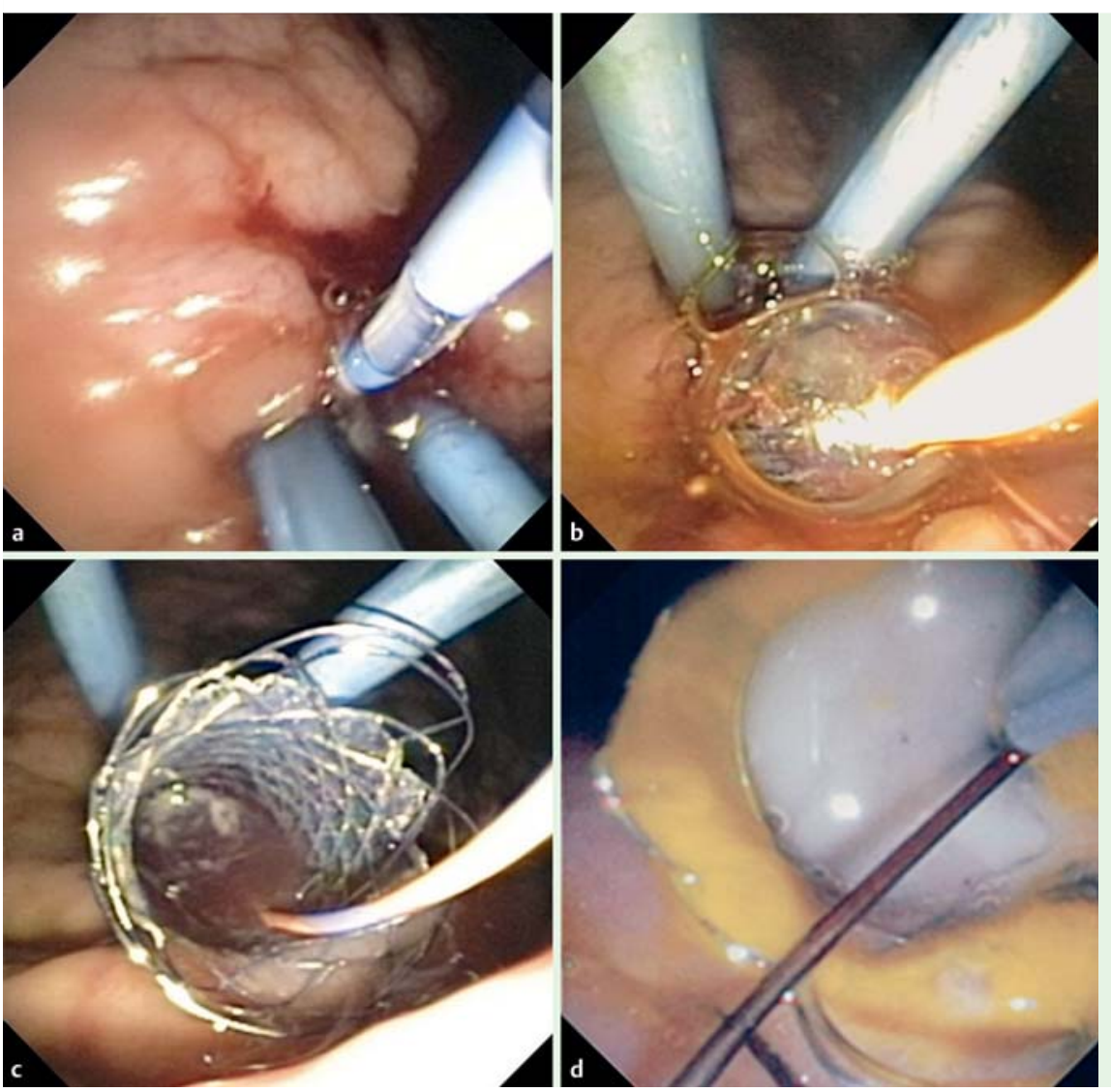

Fig. 2 Endoscopic extra-cavitary approach. (a) The cystogastrostomy was initially created by inserting plastic double pigtail stents. (b) The tract was dilated with a balloon. (c) Once the fully covered selfexpanding metal stent (fCSEMS) was in place, the cavity was accessed with a wire and a catheter. (d) The staged debridement was performed using a biliary catheter inserted through or beside the metal stent. The catheter was connected to a water jet system.

via fluoroscopy. The needle was exchanged for a tapered-tip, 5-Fr biliary catheter (Conmed, Utica, NY, USA) that was advanced over the wire to enlarge the opening. Afterwards, the biliary catheter was exchanged for a 10-mm biliary balloon (Boston Scientific, Winston Salem, NC, USA) and the cystenterostomy tract was dilated followed by insertion of at least two 7-Fr, 4-cm double pigtail stents (Cook) ( Fig. 1). The presence of plastic stents allows for initial cavitary decompression. Later, the presence of plastic stents allows for a smoother removal of the SEMS. Subsequently, a $10-\mathrm{mm}$ diameter (60-80 mm length) fcSEMS (Boston Scientific) was placed alongside the plastic stents ( $\bullet$ Fig. 1 and $\bullet$ Fig. 2). The initial irrigation was performed with gastroscopes or duodenoscopes. The key aspect of the debridement was the insertion of a tapered-tip, 5-Fr biliary catheter through the fcSEMS into the cavity with subsequent saline lavage, initially using syringes and then attached to a water pump, Olympus endoscopic flushing pump [4] ( $\bullet$ Fig. 1 and $\bullet$ Fig. 2). The patient presented in the case report explaining the technique was part of this study [4]. The initial four procedures were performed using syringes and then the technique was performed using the flushing pump. For the purpose of saline lavage using the water jet system, we used a duodenoscope (Olympus, Tokyo, Japan). The amount of saline used for forceful irrigation and lavage varied from 700 to 1200 $\mathrm{mL}$. Careful attention was paid to measuring the output of the cavity into the stomach. Constant suction was applied through the endoscope during the entire procedure and the removed liquid/debris was measured in the suctioning container. The aim was to remove the same amount of liquid as injected into the cavity, with an expected variation of $<100 \mathrm{~mL}$. The patients were then brought back for repeated endoscopic lavages of the WON. The frequency of lavage/debridement was scheduled based on the size of the WON and the clinical condition. Patients with collections $>15 \mathrm{~cm}$ and those with ongoing systemic inflammatory response syndrome (defined as the presence of leukocytosis 
Table 2 Summary of the results of our study utilizing fully covered self-expanding metal stents (fCSEMS) for drainage of walled-off pancreatic necrosis (WON).

\begin{tabular}{|c|c|c|c|c|c|c|c|c|c|c|}
\hline Study & $\begin{array}{l}\text { No. of } \\
\text { patients }\end{array}$ & $\begin{array}{l}\text { No. of pro- } \\
\text { cedures (by } \\
\text { patient) }\end{array}$ & Etiology & $\begin{array}{l}\text { Largest } \\
\text { diameter } \\
(\mathrm{cm})\end{array}$ & Location & Complications & $\begin{array}{l}\text { Technical } \\
\text { success } \\
(\%)\end{array}$ & $\begin{array}{l}\text { Clinical } \\
\text { success } \\
(\%)\end{array}$ & $\begin{array}{l}\text { With stent } \\
\text { (wk) }\end{array}$ & $\begin{array}{l}\text { Follow- } \\
\text { up (wk) }\end{array}$ \\
\hline $\begin{array}{l}\text { Our } \\
\text { study }\end{array}$ & 17 & 13 & $\begin{array}{l}\text { Gallstone } \\
\text { pancreatitis }\end{array}$ & 18.6 & 1 & None & 100 & 88 & $\begin{array}{l}31,20,25 \\
22,31,18\end{array}$ & 3 \\
\hline- & - & 7 & Unknown & 5.6 & Body/tail & $\begin{array}{l}\text { Obstructive } \\
\text { jaundice or dila- } \\
\text { ted BD }\end{array}$ & & & $\begin{array}{l}\text { Not } \\
\text { inserted }\end{array}$ & 10 \\
\hline - & - & 3 & $\mathrm{ETOH}$ & 11.2 & $\begin{array}{l}\text { Into the gastro- } \\
\text { hepatic liga- } \\
\text { ment and } \\
\text { peripancreatic } \\
\text { extending in- } \\
\text { feriorly along } \\
\text { the mesenteric } \\
\text { root }\end{array}$ & $\begin{array}{l}\text { Reintervention } \\
9 \text { d later after } \\
\text { abdominal pain } \\
\text { and fever; rein- } \\
\text { tervention } 4 \mathrm{~d} \\
\text { later after ab- } \\
\text { dominal pain } \\
\text { and fever }\end{array}$ & & & $\begin{array}{l}13, \text { not } \\
\text { removed; } \\
4, \text { not } \\
\text { removed }\end{array}$ & 1 \\
\hline - & - & 8 & $\mathrm{ETOH}$ & 1 & Neck & $\begin{array}{l}\text { Hematobilia } w / \\
\text { procedure on } \\
8 / 1 / 2013\end{array}$ & & & $\begin{array}{l}24, \text { not } \\
\text { removed; } \\
\text { not re- } \\
\text { moved; not } \\
\text { removed }\end{array}$ & 1 \\
\hline - & - & 6 & $\begin{array}{l}\text { Gallstone } \\
\text { pancreatitis }\end{array}$ & 11.2 & Lobe & None & & & 26 & 53 \\
\hline - & - & 5 & Unknown & 9.6 & Tail & None & & & 63,63 & 0 \\
\hline- & - & 6 & $\begin{array}{l}\text { Gallstone } \\
\text { pancreatitis }\end{array}$ & 8.2 & Body & None & & & 37,78 & 18 \\
\hline - & - & 6 & $\begin{array}{l}\text { Gallstone } \\
\text { pancreatitis }\end{array}$ & 26 & Head & $\begin{array}{l}\text { Pseudocyst } \\
\text { enlargement } \\
\text { and taken to OR } \\
\text { for cyst } \\
\text { gastrostomy }\end{array}$ & & & $\begin{array}{l}82,82,82, \\
69\end{array}$ & 4 \\
\hline- & - & 3 & Unknown & 5.4 & Neck & None & & & 55 & 8 \\
\hline- & - & 2 & $\mathrm{ETOH}$ & 11.2 & $\begin{array}{l}\text { Lesser curva- } \\
\text { ture, behind the } \\
\text { stomach }\end{array}$ & $\begin{array}{l}\text { Died } 3 \mathrm{~d} \text { after } \\
\text { procedure, } \\
\text { made comfort } \\
\text { care after ARDS } \\
\text { from vent and } \\
\text { AKI }\end{array}$ & & & $\begin{array}{l}\text { Not } \\
\text { removed }\end{array}$ & 0 \\
\hline - & - & 2 & $\mathrm{ETOH}$ & 1 & Perigastric & None & & & $\begin{array}{l}\text { Not } \\
\text { removed }\end{array}$ & 0 \\
\hline- & - & 6 & $\begin{array}{l}\text { Gallstone } \\
\text { pancreatitis }\end{array}$ & 6.4 & Head & None & & & 62 & 9 \\
\hline- & - & 5 & $\begin{array}{l}\text { Gallstone } \\
\text { pancreatitis }\end{array}$ & 4 & Head & None & & & 23,23 & 6 \\
\hline- & - & 4 & Unknown & 9.2 & $\begin{array}{l}\text { Posterior to } \\
\text { transverse } \\
\text { colon, extend- } \\
\text { ing superiorly } \\
\text { along the } \\
\text { spleen }\end{array}$ & $\begin{array}{l}\text { Poor PO intake, } \\
\text { fever, nausea, } \\
\text { abdominal } \\
\text { pain; readmit- } \\
\text { ted } 10 \text { d later }\end{array}$ & & & 13 & 4 \\
\hline- & - & 3 & Unknown & 6.7 & Head & None & & & $\begin{array}{l}\text { Not } \\
\text { removed }\end{array}$ & 0 \\
\hline- & - & 2 & Unknown & 4 & $\begin{array}{l}\text { Pancreatic } \\
\text { parenchyma }\end{array}$ & None & & & 87 & 6 \\
\hline- & - & 3 & $\mathrm{ETOH}$ & 5.2 & Tail & None & & & $\begin{array}{l}30, \text { not } \\
\text { removed }\end{array}$ & 1 \\
\hline
\end{tabular}

Abbreviations: AKI, acute kidney injury; ARDS, acute respiratory distress syndrome; BD, bile duct; ETOH, ethanol; PO, by mouth.

* Not mentioned.

$>14000 \mu \mathrm{L}$, temperature $>38.5^{\circ} \mathrm{C}$, tachycardia $>100 \mathrm{bpm}$ [beats per minute]) underwent ED lavages every 48 to 72 hours. No endoscopic intra- or trans-cavitary exploration was performed. Follow-up endoscopy for stent removal was optimally scheduled 6 to 8 weeks after initial ED, with a prior computed tomography (CT) to confirm resolution of the WON.
A pancreatogram was ideally obtained once to evaluate the pancreatic duct integrity. In the event of a pancreatic duct disruption, pancreatic duct sphincterotomy and transpapillary pancreatic duct stent placement were attempted. Follow-up ERCP for stent removal was optimally scheduled 6 weeks after initial ED of the WON, with a prior CT to confirm resolution of the WON. 



Fig. 3 Walled-off necrosis (WON). (a) Large WON. (b) Another key aspect was to keep a sufficiently large lumen to allow for the debris to move out of the collection. (b) The combination of metal and plastic stents may be advantageous; the larger lumen metal stent allows for debris to flow out, whereas the more deeply located plastic stents permit softening of the partially necrotic or necrotic collection and work as a pathway for these contents to move out into the gut lumen.

\section{Results}

$\nabla$

A total of 17 patients (15 men, 2 women; mean age 52.6, range 24-69; mean American Society of Anesthesiologists [ASA] score of 3) underwent ED drainage of WON. The etiologies of the PFC were gallstones ( 6 patients); alcohol (5 patients); and idiopathic (6 patients). The symptoms that indicated a requirement for drainage were abdominal pain $(n=8)$; fever, nausea/vomiting, and abdominal pain $(n=3)$; fever and abdominal pain $(n=2)$; nausea/vomiting and abdominal pain $(\mathrm{n}=2)$; asymptomatic $(\mathrm{n}=$ $1)$; and fever $(n=1)$. The mean initial PFC diameter was $9.5 \pm 5.9$ $\mathrm{cm}$, ranging from 8.0 to $26.0 \mathrm{~cm}$ ( $\odot$ Table 2, $\odot$ Fig. 2 and $\odot$ Fig. 3 ). The mean stenting period was 42.5 days (range $4.0-87.0 \mathrm{~d}$ ). In 9 of 17 patients in whom pancreatograms were able to be obtained, no patients had pancreatic duct disruption requiring pancreatic duct sphincterotomy and stenting. Table 2 summarizes the clinical, endoscopic, and outcome data of our study.

Initial technical success was achieved in $100 \%$ of the cases ( $\bullet$ Table 1). Clinical success was achieved in 14 of 17 patients (82.3\%). One patient underwent operation for enlarging PFC (surgical cystogastrostomy with necrosectomy, $\mathrm{n}=1$ ) and one patient underwent percutaneous drainage in addition to ED. One patient died due to ongoing severe sepsis 3 days after the procedure. Adverse events directly related to the procedure occurred in 3 patients (17.6\%). The patients were discharged home after time spans ranging from 2 hours to 3 months and 23 days. The average number of ED per patient was $4.9 \pm 2.8$, range 1 to 8 . The mean duration of ED using irrigation was 35 minutes (range 25-65 min). Of the 17 patients, 14 patients $(82.35 \%$ ) had a complete resolution of the PFC, which were assessed by CT scan and EUS analysis. The total number of hospital days from the time of first intervention to final stent removal was 25 days (range 18-92d). SEMS were removed without difficulty by looping the proximal end of the stent with a polypectomy snare and pulling the stent into the stomach. The mean follow-up was $7.3 \pm 12.7$ weeks, ranging from 0 to 53 weeks.

\section{Discussion}

In this study we found that staged endoscopic extra-cavitary lavage and debridement of complex WON with large-volume saline solution injected through a biliary catheter is a minimally invasive, feasible method with high technical and clinical success and low rate of severe complications. The use of a high-flow water jet system made our technique more efficient. It is well known that ED of WON is feasible [1-3]. Recent data show that maintaining a large opening to the cavity is a key element to al- low for drainage of thick material [4-9]. A useful method to allow for long-term patency to the WON is the insertion of a fcSEMS [4-12]. These fcSEMS can be placed easily, open up the fistula to $10 \mathrm{~mm}$, and maintain patency for the duration of the drainage of PFC [1,3,5-7]. However, in many of these studies, most of the PFC included were acute and chronic pseudocysts ( Table 1). WON or PFC with significant solid contents (>50\%) were excluded or present in low numbers [5-10]. Endoscopic approaches to treat organized pancreatic necrosis have progressed from making small transmural tracts for irrigation to making large tracts that allow the endoscope to move directly into necrotic cavities and perform endoscopic necrosectomy [13]. This has allowed significant decrease in need for adjuvant percutaneous drains [13].

In Yamamoto et al., 4 of the 9 patients in the study had WON. SEMS were removed after 5.7 weeks in 1 patient and 3.6 weeks in another [3]. In Tarantino et al., 1 patient had necrotizing acute pancreatitis [7]. Technical success and clinical success were achieved without complications [7]. SEMS was removed after 12 weeks. Hritz et al. reported 3 patients with infected WON and 1 patient with pancreatic abscess who underwent DEN 19-21 days after the onset of acute pancreatitis [14]. Clinical success was achieved in $75 \%$ of patients [14]. In Fabbri et al., 10 patients had either a pancreatic abscess or infected pancreatic necrosis [15]. One had a complication of migration and sepsis [15]. Complete resolution was seen in all patients where drainage was attempted [15]. In Berzosa et al., 2 of 7 patients in the study had WON [1]. Presenting symptoms for both patients were fever, pain, and vomiting. Both patients had two collections with the largest diameter being $6 \mathrm{~cm}$ (located in the body) and $8 \mathrm{~cm}$ (located in the tail) in 1 patient, and $6 \mathrm{~cm}$ (located in the neck) and $4 \mathrm{~cm}$ (located in the body) in another patient [1]. Technical success and clinical success were achieved in both patients without complications [1]. SEMS were placed for 11 and 8 weeks [1]. Thus, an advantage of our study is that we only included patients with WON, which is intrinsically more challenging to drain completely given the solid content.

In Ross et al., 15 patients with organized pancreatic necrosis underwent successful CT-guided percutaneous drainage followed by endoscopic transenteric drainage, with 25 total endoscopies being performed subsequent to initial drainage [16]. After mean follow-up of 189 days, percutaneous drains were removed from 13 patients [16]. Late complications included parenchymal infection in 1 patient after drain removal [16].

In comparison to most published data on fcSEMS for drainage of WON, our method is less invasive due to its extra-cavitary approach. This aspect of drainage makes our procedure different from most previously reported studies, in which an active intra- 
or trans-cavitary drainage technique was used [2-10]. In Yamamoto et al., DEN was performed in 3 patients with means of 9, 4, and 3 sessions [3]. Clinical success was achieved in 2 of 4 patients (50\%) with WON [3]. In 1 patient, DEN could not be completed due to intracystic bleeding and patient underwent surgical necrosectomy [3]. In one patient, insertion of a nasal tube and performance of procedure were not possible given violent behavior due to delirium [3]. Another patient suffered a late complication of bleeding and died from multiorgan failure [3]. In Seifert et al., 93 patients underwent direct transluminal endoscopic removal of pancreatic necroses (mean of 6 interventions), with $80 \%$ of patients having initial clinical success [17]. There was a $26 \%$ complication rate and a $7.5 \%$ mortality rate at 30 days [17]. DEN was also performed in Gardner et al. and successful resolution was achieved in $91 \%$ of patients (95 of 104 patients), with a mean time to resolution from initial DEN of 4.1 months and a mean number of 3 procedures with 2 debridements [18]. In those in whom the procedure failed, 5 died during follow-up, 2 had operative drainage for persistent WON, 1 required surgery for massive bleeding on fistula tract dilation, and 1 died perioperatively [18]. Complications occurred in $14 \%$ of patients and included 5 retrogastric perforations or pneumoperitoneum [18]. In the technique presented by Hritz et al., following stent deployment, a nasobiliary pigtail catheter was placed into the cavity to ensure continuous irrigation [14]. After 5 to 7 days, the metal stent was removed and the cavity was entered with a therapeutic gastroscope [14]. Intra-cavitary debridement was performed via flush knife, a Dormia basket, and hot biopsy forceps. ED was repeated 2 to 5 times daily during the next 10 days and clinical success was achieved in $75 \%$ of patients [14]. In a recent case series, 11 of 14 patients had successful hydrogen peroxide DEN for symptomatic WON with a mean number of 3 necrosectomies (range 1 - 7) [19]. In 7 of the 11 patients, irrigation of the cavity on initial endoscopy was so effective that no further mechanical debridement was required on follow-up endoscopy [19]. Resolution of the cavity failed in 3 patients, with a need for CT-guided percutaneous catheter drainage $(n=1)$, required surgery as a result of DENrelated gastric perforation $(n=1)$, and death as a result of sepsis unrelated to the endoscopic procedure $(n=1)$ [19]. Adverse events occurred in $28 \%$ of patients and included pneumoperitoneum $(n=1)$, bacteremia after the procedure $(n=2)$, and stentrelated gastric perforation requiring surgery $(n=1)$ [19]. Baron and Kozarek were the first to describe saline lavage through nasocystic catheter [13]. However, we believe that direct ED using a catheter and endoscopic control allows for a more controlled application of saline and suctioning of debris. Despite a greater number of ED sessions, our data show that complete resolution of complex PFC was achieved in a substantial portion of patients with minimal adverse events.

It appears that although trans-cavitary ED allows for the removal of solid necrotic debris, it is associated with high morbidity and mortality-up to 12 to $56 \%$ [5]. Complications of direct (intra-cavitary) ED include peritonitis, bleeding, and perforation [3]. Our method is less invasive because it is mainly based on debridement or lavage of a PFC. Therefore, a potential disadvantage of our proposed method is the necessity to undergo multiple sessions. However, the gentler debridement with its potentially lower morbidity may offset the inconvenience of staged endoscopies. Another key aspect for the success of ED is the presence of a stable lumen between the gastrointestinal tract and the cavity. This is guaranteed by the fcSEMS that creates an apposition of the two-gastrointestinal lumen and WON-becoming a conduit for multiple transenteric endoscopic interventions including DEN and lavages [9]. The larger lumen stent or stents serve to provide access into the WON, aiding faster drainage with minimal risk of obstruction and allowing debridement and/or washings to occur. There are several methods described to endoscopically drain WON using fcSEMS $[1,3,5,7]$. However, there is no large prospective study comparing different approaches on a prospective basis. In Belle et al., all 4 patients in the study had WON and the indication for treatment was infection [5]. Technical success and clinical success were achieved in all 4 patients, with 1 patient having transitory outlet obstruction [5]. SEMS were explanted at 4, 5, 9, and 147 weeks [5].

The success rate of our study of $82.5 \%$ was comparable to more aggressive intra-cavitary approaches $[1,3,5-7,15]$. We believe that the repetitive lavage using a high-flow system and the presence of a sufficiently large conduit to allow for the semiliquid debris to flow out were the key factors for success. Although there were also complications in our study, only one instance was severe, which compares favorably with the reported literature on ED of WON $[1,3,5-7,20]$. Nevertheless, our study was not set up to be a comparison with established methods; only a randomized, comparative study can answer the questions of which method is more efficacious and safer. Our study had some potential limitations: a tertiary care center, retrospective design, nonrandomization, a relatively small sample size, and short-term follow-up. However, our data were based on a careful, prospectively collected database on all pancreatobiliary procedures. In addition, the patients are all discussed at our interdisciplinary radiology and clinical conferences. Despite having performed some procedures under monitored anesthesia care, we believe that conducting ED of complex PFC should be done only under general anesthesia-mainly to protect the patient's airways.

In summary, we conclude that ED of complex WON with fCSEMSfollowed by repeated endoscopic extra-cavitary lavage and debridement using a biliary catheter and high-flow water jet systemis a minimally invasive, feasible method with high technical and clinical success and minimal adverse events. Although our results are promising, future prospective studies are needed to validate our technique and compare with other methods of ED for WON.

\section{Competing interests: None}

\section{References}

1 Berzosa M, Maheshwari S, Patel KK et al. Single-step endoscopic ultrasonography-guided drainage of peripancreatic fluid collections with a single self-expandable metal stent and standard linear echoendoscope. Endoscopy 2012; 44: 543-547

2 Stamatakos M, Stefanaki C, Kontzoglou K et al. Walled-off pancreatic necrosis. World J Gastroenterol 2010; 16: 1707-1712

3 Yamamoto $\mathrm{N}$, Isayama $\mathrm{H}$, Kawakami $\mathrm{H}$ et al. Preliminary report on a new, fully covered, metal stent designed for the treatment of pancreatic fluid collections. Gastrointest Endosc 2013; 77: 809-814

4 Gutierrez JP, Wilcox CM, Mönkemüller K. New technique to carry out endoscopic necrosectomy lavage using a pump. Dig Endosc 2013; 26: $117-118$

5 Belle S, Collet P, Post $S$ et al. Temporary cystogastrostomy with self-expanding metallic stents for pancreatic necrosis. Endoscopy 2010; 42: 493-495

6 Penn DE, Draganov PV, Wagh MS et al. Prospective evaluation of the use of fully covered self-expanding metal stents for EUS-guided transmural drainage of pancreatic pseudocysts. Gastrointest Endosc 2012; 76: 679-684

7 Tarantino I, Traina M, Barresi $L$ et al. Treatment of infected pancreatic pseudocysts using a novel, dedicated covered self-expandable metal stent (CSEMS) with an effective antimigration system. Endoscopy 2012; 44: E147-E148 
8 Talreja JP, Shami VM, Ku J et al. Transenteric drainage of pancreaticfluid collections with fully covered self-expanding metallic stents. Gastrointest Endosc 2008; 68: 1199-1203

9 Itoi T, Nageshwar Reddy D, Yasuda I. New fully-covered self-expandable metal stent for endoscopic ultrasonography-guided intervention in infectious walled-off pancreatic necrosis (with video). J Hepatobiliary Pancreat Sci 2013; 20: 403-406

10 Gluck M, Ross A, Irani $S$ et al. Endoscopic and percutaneous drainage of symptomatic walled-off pancreatic necrosis reduces hospital stay and radiographic resources. Clin Gastroenterol Hepatol 2010; 8: 1083 1088

11 Thoeni RF. The revised Atlanta classification of acute pancreatitis: its importance for the radiologist and its effect on treatment. Radiology 2012; 262: 751-764

12 Binmoeller K, Smith I, Gaidhane M et al. A kit for EUS-guided access and drainage of pancreatic pseudocysts: efficacy in a porcine model. Endoscopic Ultrasound 2012; 1: 137-142

13 Baron TH, Kozarek RA. Endotherapy for organized pancreatic necrosis: perspectives after 20 years. Clin Gastroenterol Hepatol 2012; 10: $1202-1207$

14 Hritz I, Fejes R, Székely A et al. Endoscopic transluminal pancreatic necrosectomy using a self-expanding metal stent and high-flow waterjet system. World J Gastroenterol 2013; 19: 3685-3692
15 Fabbri C, Luigiano C, Cennamo V et al. Endoscopic ultrasound-guided transmural drainage of infected pancreatic fluid collections with placement of covered self-expanding metal stents: a case series. Endoscopy 2012; 44: 429-433

16 Ross A, Gluck M, Irani $S$ et al. Combined endoscopic and percutaneous drainage of organized pancreatic necrosis. Gastrointest Endosc 2010; 71: $79-84$

17 Seifert H, Biermer M, Schmitt $W$ et al. Transluminal endoscopic necrosectomy after acute pancreatitis: a multicentre study with long-term follow-up (the GEPARD study). Gut 2009; 58: 1260-1266

18 Gardner TB, Coelho-Prabhu N, Gordon SR et al. Direct endoscopic necrosectomy for the treatment of walled-off pancreatic necrosis: results from a multicenter U.S. series. Gastrointest Endosc 2011; 73: 718 - 726

19 Siddiqui AA, Easler J, Strongin A et al. Hydrogen peroxide-assisted endoscopic necrosectomy for walled-off pancreatic necrosis: a dual center pilot experience. Dig Dis Sci 2014; 59: 687-690

20 Hookey LC, Debroux S, Delhaye M et al. Endoscopic drainage of pancreatic fluid collections in 116 patients: a comparison of etiologies, drainage techniques, and outcomes. Gastrointest Endosc 2006; 63: 635 643 